\title{
Correction to: Effects of the COVID-19 pandemic on trauma-related emergency medical service calls: a retrospective cohort study
}

Michael Azbel ${ }^{1,2^{*}}$, Mikko Heinänen ${ }^{3,4}$, Mitja Lääperi $^{2}$ and Markku Kuisma

Correction to: BMC Emergency Medicine 21, 102 (2021)

https://doi.org/10.1186/s12873-021-00495-3

The original article [1] mistakenly removed negative values in the 'Change \% (IQR) column of Tables 1-3.

These values have now been corrected.

\author{
Author details \\ 'Prehospital Emergency Care Services, Lapland Central Hospital, P.O. Box, \\ 8041, Fl-96101 Rovaniemi, Finland. ${ }^{2}$ Department of Emergency Medicine and \\ Services, Helsinki University and Helsinki University Hospital, P.O. Box 340, \\ Fl-00029 Helsinki, Finland. ${ }^{3}$ Trauma Unit and Helsinki Trauma Registry, \\ Helsinki University Hospital, P.O. Box 266, Fl-00029 Helsinki, Finland. \\ ${ }^{4}$ Department of Orthopaedics and Traumatology, University of Helsinki and \\ Helsinki University Hospital, Helsinki, Finland.
}

Published online: 19 November 2021

\section{Reference}

1. Azbel M, Heinänen M, Lääperi M, Kuisma M. Effects of the COVID-19 pandemic on trauma-related emergency medical service calls: a retrospective cohort study. BMC Emerg Med. 2021;21(1):102. https://doi. org/10.1186/s12873-021-00495-3.

The original article can be found online at https://doi.org/10.1186/s12873021-00495-3.

* Correspondence: michael.azbel@|shp.fi

'Prehospital Emergency Care Services, Lapland Central Hospital, P.O. Box, 8041, Fl-96101 Rovaniemi, Finland

${ }^{2}$ Department of Emergency Medicine and Services, Helsinki University and Helsinki University Hospital, P.O. Box 340, Fl-00029 Helsinki, Finland

Full list of author information is available at the end of the article

(c) The Author(s). 2021 Open Access This article is licensed under a Creative Commons Attribution 4.0 International License, which permits use, sharing, adaptation, distribution and reproduction in any medium or format, as long as you give appropriate credit to the original author(s) and the source, provide a link to the Creative Commons licence, and indicate if changes were made. The images or other third party material in this article are included in the article's Creative Commons. licence, unless indicated otherwise in a credit line to the material. If material is not included in the article's Creative Commons licence and your intended use is not permitted by statutory regulation or exceeds the permitted use, you will need to obtain permission directly from the copyright holder. To view a copy of this licence, visit http://creativecommons.org/licenses/by/4.0/ The Creative Commons Public Domain Dedication waiver (http://creativecommons.org/publicdomain/zero/1.0/) applies to the data made available in this article, unless otherwise stated in a credit line to the data. 